\title{
Vertical Distribution of Bio-Optical Properties of the Azov - Black Sea Basin Waters in April - May, 2019
}

\section{T. V. Efimova*, T. Ya. Churilova, E. Yu. Skorokhod, N. A. Moiseeva, E. A. Zemlianskaia}

\author{
A. O. Kovalevsky Institute of Biology of the Southern Seas, Russian Academy of Sciences, \\ Sevastopol, Russian Federation \\ * tefimova@ibss-ras.ru
}

Purpose. The work is aimed at investigating spatial distribution of the chlorophyll a concentration and the spectral light absorption coefficients by all optically active components in the Azov and Black seas in spring, when the seawater hydrophysical structure changes.

Methods and Results. The data collected in the $106^{\text {th }}$ scientific cruise of R/V Professor Vodyanitsky in April 19 - May 10, 2019 were used. The chlorophyll a concentration was measured by the spectrophotometric method. The spectral light absorption coefficients were determined in accordance with the NASA protocol 2018. The optical measurements were performed using the dualbeam spectrophotometer Lambda 35 (PerkinElmer). It was shown that in the surface layer of the Black Sea, the chlorophyll $a$ concentration varied from 0.21 to $1.2 \mathrm{mg} / \mathrm{m}^{3}$. At some stations in the deep-water region, the increased values of this parameter were observed in the lower part of the euphotic zone that was associated with the beginning of seasonal water stratification due to the surface water heating. At these stations, the phytoplankton absorption spectra were more smoothed in the lower part of the euphotic zone than those in the upper layer. In the deep-water region, the non-algal particles contribution to the total particulate light absorption at wavelength $438 \mathrm{~nm}$ changed with depth from $40 \pm 15 \%$ at the surface to $29 \pm 12 \%$ near the bottom of the euphotic zone; whereas in the coastal waters this parameter was almost unchangeable within the water column (54 $\pm 11 \%)$. No significant change of the colored dissolved organic matter contribution to the total light absorption with depth was revealed (69\% on average). In the Sea of Azov, vertical distribution both of the chlorophyll $a$ concentration (6.2 mg/m $\mathrm{m}^{3}$ on average) and the spectral light absorption coefficients by all the optically active components was uniform. The non-algal particles contribution to the particulate light absorption was $40 \pm 14 \%$, and the colored dissolved organic matter contribution to the total light absorption constituted $52 \pm 6 \%$.

Conclusions. New data on spatial distribution of the chlorophyll $a$ concentration and the spectral light absorption coefficients by the optically active components in the Black and Azov seas were obtained for the spring period when the seawater hydrophysical characteristics changed.

Keywords: chlorophyll $a$, spectral light absorption coefficients, non-algal particles, colored dissolved organic matter, Black Sea, Sea of Azov.

Acknowledgments: the research was funded by Russian Academy of Sciences (grant No. AAAAA19-119061190081-9) and partially supported by the Russian Foundation for Basic Research (grants No. 18-45-920070 and 18-05-80025).

For citation: Efimova, T.V., Churilova, T.Ya., Skorokhod, E.Yu., Moiseeva, N.A. and Zemlianskaia, E.A., 2020. Vertical Distribution of Bio-Optical Properties of the Azov - Black Sea Basin Waters in April-May, 2019. Physical Oceanography, [e-journal] 27(5), pp. 525-534. doi:10.22449/1573-160X-2020-5-525-534

DOI: $10.22449 / 1573-160 X-2020-5-525-534$

(C) T. V. Efimova, T. Ya. Churilova, E. Yu. Skorokhod, N. A. Moiseeva, E. A. Zemlianskaia, 2020

(C) Physical Oceanography, 2020 


\section{Introduction}

The optically active components of the aquatic environment are phytoplankton, non-algal particles and colored dissolved organic matter. The distribution of phytoplankton in the water column is influenced by irradiance, temperature and nutrient availability. Analysis of the spatial distribution of chlorophyll $a$ concentration and spectral light absorption by all optically active components revealed their variability regularities depending on the hydrophysical factors during the spring hydrological structure changes. These regularities are necessary for the development of regional model of chlorophyll $a$ concentration in the surface layer [1], vertical distributions of chlorophyll $a$ concentration [2] and spectral model of downwelling irradiance [3] in the Black and Azov seas, taking into account the seasonal characteristics of the environment.

The work is aimed to study spatial distribution of the chlorophyll $a$ concentration and the spectral light absorption coefficients by all the optically active components in the Azov and Black seas in spring, when the seawater hydrological structure changes.

\section{Material and methods}

The measurements of the spectral bio-optical properties of the Azov and Black sea basin waters were carried out in the $106^{\text {th }}$ scientific cruise of R/V Professor Vodyanitsky in April 19 - May 10, 2019 (Fig.1).

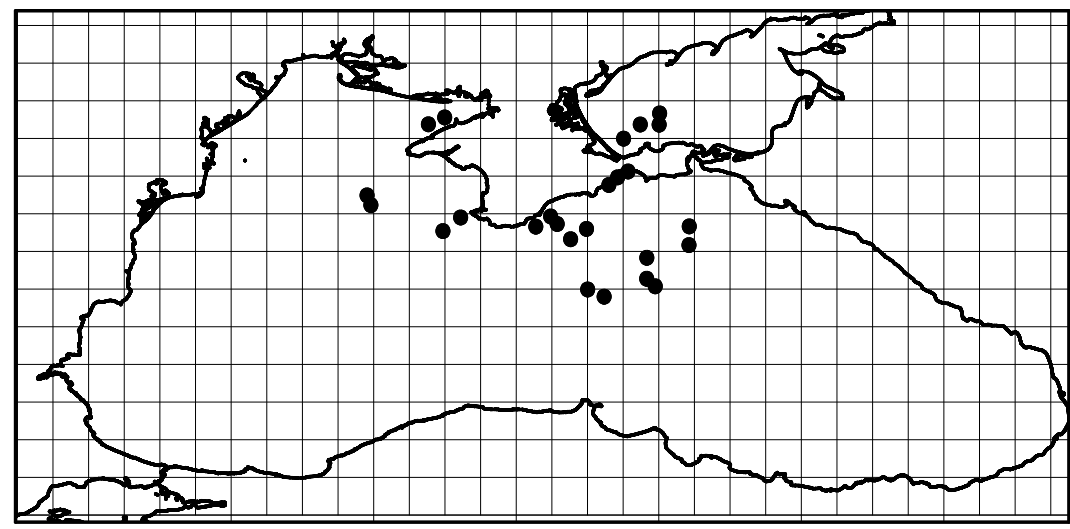

F i g. 1. Map of location of bio-optical stations in the $106^{\text {th }}$ cruise of R/V "Professor Vodyanitsky", April 19 - May 10, 2019

Water samples $(4 \mathrm{~L})$ were collected at various depths within the $0-70 \mathrm{~m}$ layer at daytime stations with Niskin bottle. The sampling depths were chosen based on the vertical profiles of temperature, chlorophyll $a$ fluorescence, penetrating photosynthetically available radiation (PAR), and water transparency. Water transparency was assessed by Secchi disk depth visibility $\left(Z_{s}\right)$. Vertical profiles of temperature, chlorophyll $a$ fluorescence and PAR were obtained using an Idronaut Ocean Seven 320Plus CTD. 
The euphotic zone $\left(Z_{\mathrm{eu}}\right)$ in the Black Sea was determined as depth with $1 \%$ of PAR incident on the sea surface. In the Azov Sea, where the PAR sensor was not used, $Z_{\mathrm{eu}}$ was calculated based on the dependence of light $(I)$ attenuation with depth $(z)$ :

$$
I(z)=I(0) \exp \left(-k_{\mathrm{d}} z\right),
$$

where $k_{\mathrm{d}}$ is the diffuse light attenuation coefficient on the average for the $Z_{\mathrm{eu}}$ layer for the PAR. The euphotic zone depth was calculated based on the Equation (1):

$$
Z_{\mathrm{eu}}=4.6 / k_{\mathrm{d}} \text {. }
$$

Values of $k_{\mathrm{d}}$ ware calculated based on the $Z_{\mathrm{s}}$ values, using the dependence [4, p. 68].

To determine the chlorophyll $a$ concentration in sum with phaeopigment $(C h l-a)$ and the spectra of light absorption by suspended matter and phytoplankton pigments, $1-2 \mathrm{~L}$ water samples were gently vacuum filtered $(\sim 0.2 \mathrm{~atm})$ through glass fiber filters (Whatman GF/F). Filters with a sample for the Chl-a determination were wrapped in an aluminum foil. Filters with samples for particulate light absorption spectra determination were placed in plastic holders. The samples were stored in a liquid nitrogen under the necessary conditions [5] until analysis on a laboratory. To determine the spectra of light absorption by colored dissolved organic matter (CDOM), $0.2 \mathrm{~L}$ samples were gently vacuum filtered $(\sim 0.2 \mathrm{~atm})$ through a nucleopore filter (Sartorius) with a pore size of $0.2 \mu \mathrm{m}$.

Chl-a in the sea was determined spectrophotometrically [6].

The determination of the spectral light absorption coefficients by suspended and dissolved organic matter was carried out in accordance with the modern NASA protocol [7]. Particulate light absorption was determined by the filter pad technique ("wet filter technique") $[8,9]$. Phytoplankton light absorption $\left(a_{\mathrm{ph}}(\lambda)\right)$ was calculated by the difference between total particulate matter absorption $\left(a_{\mathrm{p}}(\lambda)\right)$ and non-algal particles absorption $\left(a_{\mathrm{NAP}}(\lambda)\right)$ according to the method described in [10]. Values of $a_{\mathrm{ph}}(\lambda)$ were calculated from measured optical densities after correction for the path length amplification factor ( $\beta$-correction) applying the quadratic equation described in [11, p. 146].

Optical measurements were made over the spectral domain from 350 to $750 \mathrm{~nm}$ (acetone extracts and suspended matter on a filter) and over the spectral domain from 250 to $750 \mathrm{~nm}(\mathrm{CDOM})$ with a dual-beam spectrophotometer LAMBDA 35 (PerkinElmer) equipped with a Spectralon integrating sphere.

Spectral distribution of light absorption coefficients by non-algal particles $\left(a_{\mathrm{NAP}}(\lambda)\right)$ and $C D O M\left(a_{\mathrm{CDOM}}(\lambda)\right)$ were described by the exponential functions

$$
a(\lambda)=a(438) \exp (-S(\lambda-438)),
$$

where $S$ is the spectral slope, $\mathrm{nm}^{-1}$, obtained as result of fitting from 400 to $700 \mathrm{~nm}$ for NAP and from 350 to $500 \mathrm{~nm}$ for CDOM.

\section{Results and discussion}

The water transparency and euphotic zone depth in the Black Sea during the study period differed significantly between the stations. In the deep-water area of the Black Sea, the $Z_{\mathrm{s}}$ values varied from 11 to $19 \mathrm{~m}$ and was $14 \mathrm{~m}$ on average. $Z_{\text {eu }}$ varied from 28 to $44 \mathrm{~m}$ and reached an average of $35 \mathrm{~m}$. The coastal zone of 
the sea was characterized by lower water transparency: $Z_{\text {s }}$ ranged from 5 to $11 \mathrm{~m}$ and averaged $7.5 \mathrm{~m}$, while $Z_{\mathrm{eu}}$ varied from 15 to $28 \mathrm{~m}$. The upper mixed layer (UML) depth, due to the spring warming of surface waters and the start of seasonal stratification, varied between stations from 3 to $50 \mathrm{~m}$.

An important indicator of productivity and water quality is the chlorophyll $a$ concentration - the main photosynthetically active pigment of phytoplankton. In the Black Sea, during the study period, the Chl- $a$ value in the surface layer varied from 0.21 to $1.2 \mathrm{mg} / \mathrm{m}^{3}$ and was $0.60 \mathrm{mg} / \mathrm{m}^{3}$ on average. Significant differences were observed in the type of the vertical distribution of Chl- $a$ values. Profiles with a homogeneous distribution of this parameter and profiles with an increase in Chl- $a$ near the bottom of euphotic zone by 1.5-2.5 times in comparison with the Chl-a values in the surface sea layer were noted (Fig. 2).
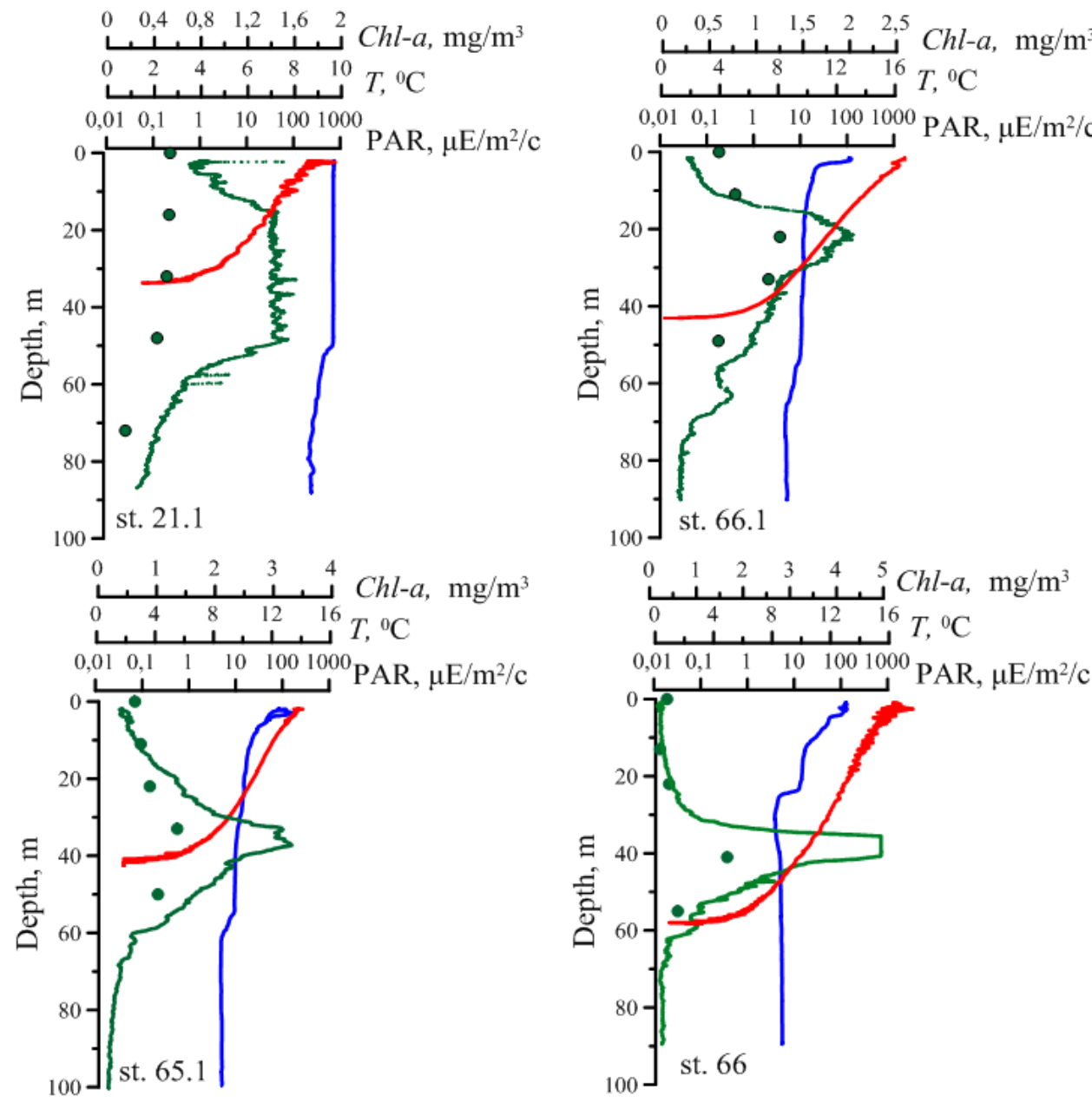

F i g. 2. Vertical distribution of the measured chlorophyll a concentration taken together with phaeopigment Chl-a (green circles) and the Chl-a data from the CTD Idronaut Ocean Seven 320 Plus (green line), temperature $T$ (blue line) and photosynthetically available radiation (PAR) (red line) at some stations in the deep part of the Black Sea in the second half of April - the first half of May, 2019 
Since spring is a transitional period when the hydrological/hydrophysical vertical structure of the waters changes, the vertical distribution of phytoplankton pigments was different at the stations. At some deep-water stations, an almost uniform vertical distribution of chlorophyll $a$, typical for winter, was still observed within the UML, bounded from below by the maximum temperature gradient layer (Fig. 2). At other stations, where, as a result of the start of seasonal waters stratification, the phytoplankton existence layer was divided by the thermocline into two quasi-isolated layers (UML and the layer below thermocline), a chlorophyll $a$ maximum appeared below the thermocline. Phytoplankton in these layers of the euphotic zone existed under various environmental conditions. Phytoplankton in the UML was under conditions of higher PAR and temperature (Fig.2), but likely with less nutrient availability than in the layer below thermocline. These differences determine changes in the structural and functional characteristics of phytoplankton existing in the upper photosynthetic zone and in the lower part of the euphotic zone, separated by a seasonal thermocline. In particular, a decrease in irradiance with depth within the euphotic zone leads to an increase in the chlorophyll $a$ content in the cells of planktonic algae inhabiting the deep layer below the thermocline $[12,13]$.

Thus, the beginning of the disturbance of the typical winter-uniform vertical Chl- $a$ distribution and an increase in the chlorophyll $a$ content in the lower part of the euphotic zone is associated with the beginning of the spring warming of surface waters and the process of the seasonal stratification formation, resulted in poor deep vertical mixing of waters.

In the spectra of light absorption by phytoplankton pigments $\left(a_{\mathrm{ph}}(\lambda)\right)$, two main peaks are noted - at wavelengths of 438 and $678 \mathrm{~nm}$ (Fig. 3). The ratio between the absorption coefficients in these peaks $(R)$ in the surface layer of the Black Sea was $2.8 \pm 0.4$. In the lower part of the euphotic zone, the $a_{\mathrm{ph}}(\lambda)$ spectra were smoother and the $\mathrm{R}$ ratio was $2.3 \pm 0.3$. Such a change in the light-absorbing capacity of phytoplankton may reflect a photoadaptive decrease in the proportion of accessory pigments carotenoids [14] with depth within the euphotic zone and a change in the size structure of phytoplankton community [15].

In the surface layer of the deep-water part of the Black Sea, the light absorption by non-algal particles at a wavelength of $438 \mathrm{~nm}$ (where the blue maximum of the $a_{\mathrm{ph}}(\lambda)$ spectrum is located) averaged $0.017 \pm 0.008 \mathrm{~m}^{-1}$, which coincides with the data obtained for the winter period of the year [16]. In this case, the relative contribution of the non-algal particles $a_{\mathrm{NAP}}(438)$ to the total light absorption by all suspended matter at a wavelength of $438 \mathrm{~nm}\left(a_{\mathrm{p}}(438)\right)$ was, on average, $40 \pm 15 \%$. In the layer from 20 to $60 \mathrm{~m}$ of the deep-water part of the Black Sea, the $a_{\mathrm{NAP}}(438)$ value was $0.014 \pm 0.006 \mathrm{~m}^{-1}$, the contribution of $a_{\mathrm{NAP}}(438)$ to $a_{\mathrm{p}}(438)$ was $29 \pm 12 \%$. In the waters of the coastal part of the Black Sea, the $a_{\mathrm{NAP}}(438)$ coefficient was two times higher $\left(0.037 \pm 0.019 \mathrm{~m}^{-1}\right)$ than in the deep-water part; the $a_{\mathrm{NAP}}(438)$ quota in $a_{\mathrm{p}}(438)$ was $54 \pm 11 \%$. The same high contribution ( $\sim 50 \%)$ of the $a_{\mathrm{NAP}}(438)$ to the total absorption by suspended matter was previously obtained in coastal waters near Katsiveli [17]. 


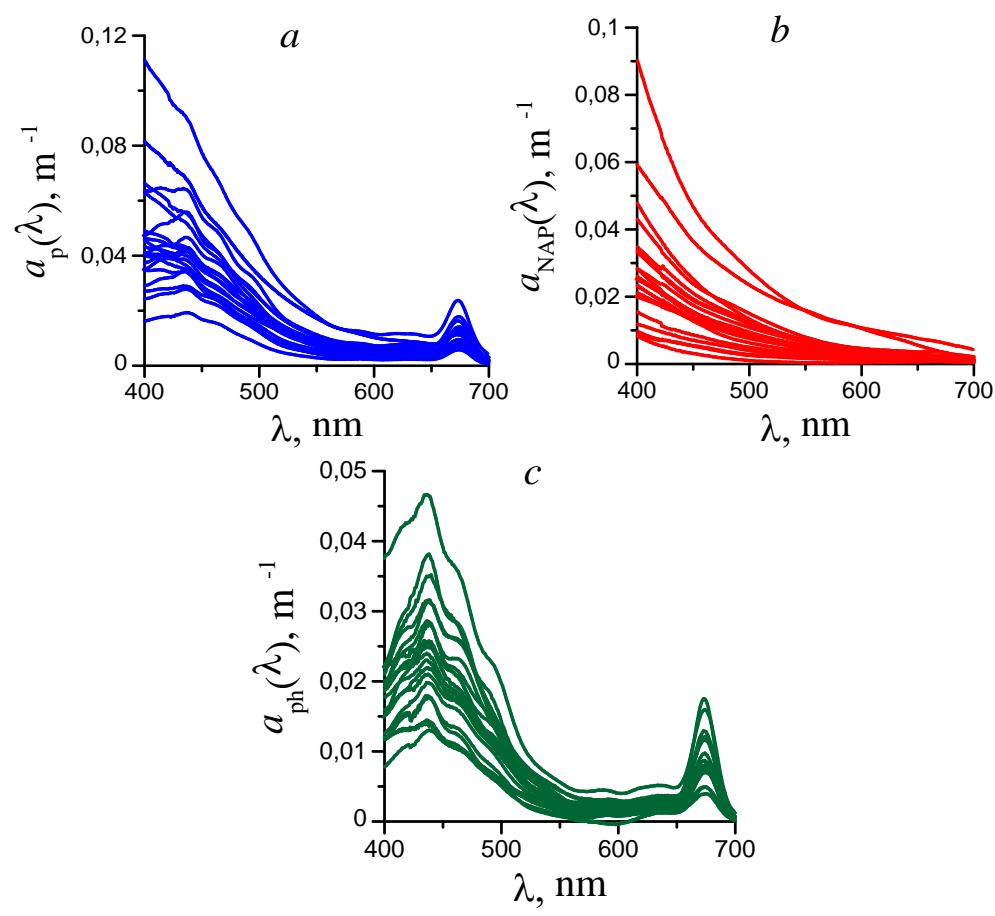

F i g. 3. Spectra of the light absorption coefficients by total particles $\left(a_{\mathrm{p}}(\lambda)\right)(a)$, non-algal particles $\left(a_{\mathrm{NAP}}(\lambda)\right)(b)$ and phytoplankton pigments $\left(a_{\mathrm{ph}}(\lambda)\right)(c)$ on the Black Sea surface in the second half of April - the first half of May, 2019

The spectral distribution $a_{\mathrm{NAP}}(\lambda)$ is described by an exponential function (Fig. 3). Analysis of the exponential coefficient $\left(S_{\mathrm{NAP}}\right)$ variability in the Black Sea area revealed its weak variability both between stations and with depth. The $S_{\mathrm{NAP}}$ value averaged $0.009 \pm 0.001 \mathrm{~nm}^{-1}$, which is consistent with the data obtained earlier for other regions of the World Ocean [18].

The CDOM light absorption coefficient at a wavelength of $438 \mathrm{~nm}$ $\left(a_{\text {СDом }}(438)\right)$ in the surface layer of the deep-water area of the Black Sea in the spring was $0.098 \pm 0.026 \mathrm{~m}^{-1}$ (Fig. 4), and in the surface layer of the coastal part $-0.13 \pm 0,05 \mathrm{~m}^{-1}$. The $a_{\mathrm{CDOM}}(438)$ contribution to the total light absorption by suspended and dissolved matter was $69 \pm 8 \%$.

The average value of the spectral slope coefficient $S_{\mathrm{CDOM}}$ in the surface layer of the Black Sea during the study period for the 350-500 nm domain was $0.017 \pm 0.002 \mathrm{~nm}^{-1}$. This does not contradict the reference data, giving $S_{\mathrm{CDOM}}$ values for different World Ocean areas in the range from 0.014 to $0.025 \mathrm{~nm}^{-1}$ [19].

It is known that the shape ( $\left.S_{\text {СDOM }}\right)$ of CDOM light absorption spectra is dependent on the chemical content of colored dissolved organic compounds: the ratio of high- and low-molecular fractions [20]. The CDOM composition in terms of the ratio of high- and low-molecular-weight organic compounds is characterized by the $S r$ value - the ratio of exponential coefficients for the wavelength domains of 275-295 and 350-400 nm [21]. It is shown that the $\mathrm{Sr}$ value in the surface layer of the deep-water and coastal parts of the Black Sea in spring was the same and averaged $1.7 \pm 0.2$. 

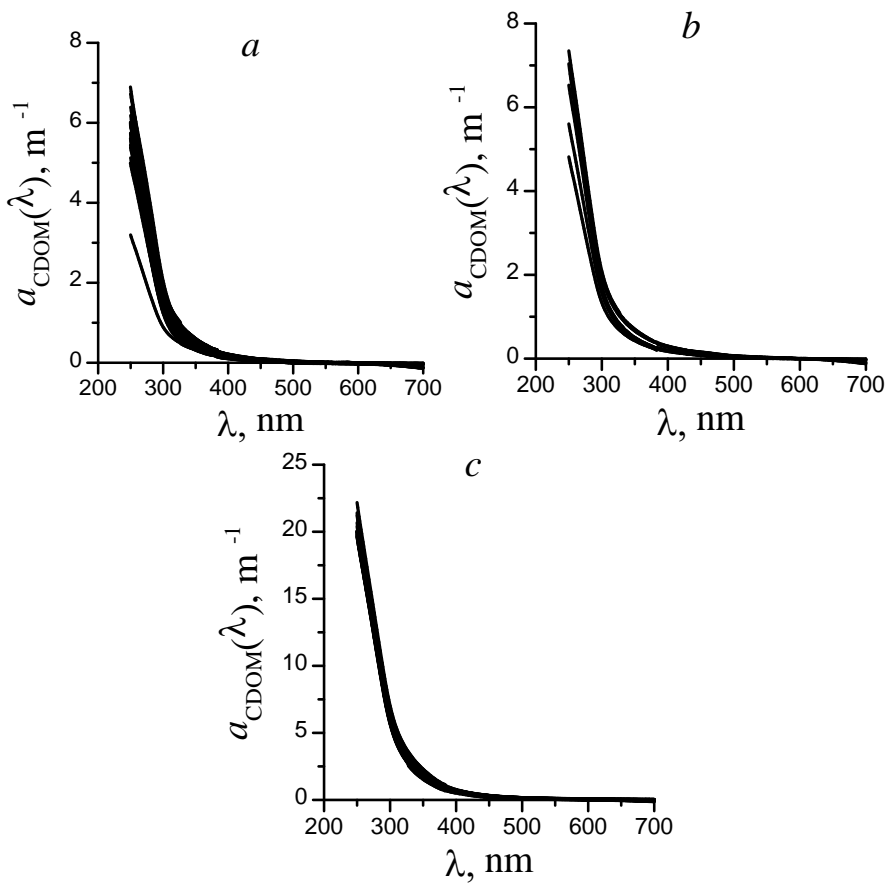

Fig. 4. Spectra of the light absorption coefficients by colored dissolved organic matter $\left(a_{\mathrm{CDOM}}(\lambda)\right)$ in the surface layer of the Black Sea deep part (a), in the surface layer of the Black Sea coastal part $(b)$ and in the Azov Sea waters (c) in the second half of April - the first half of May, 2019
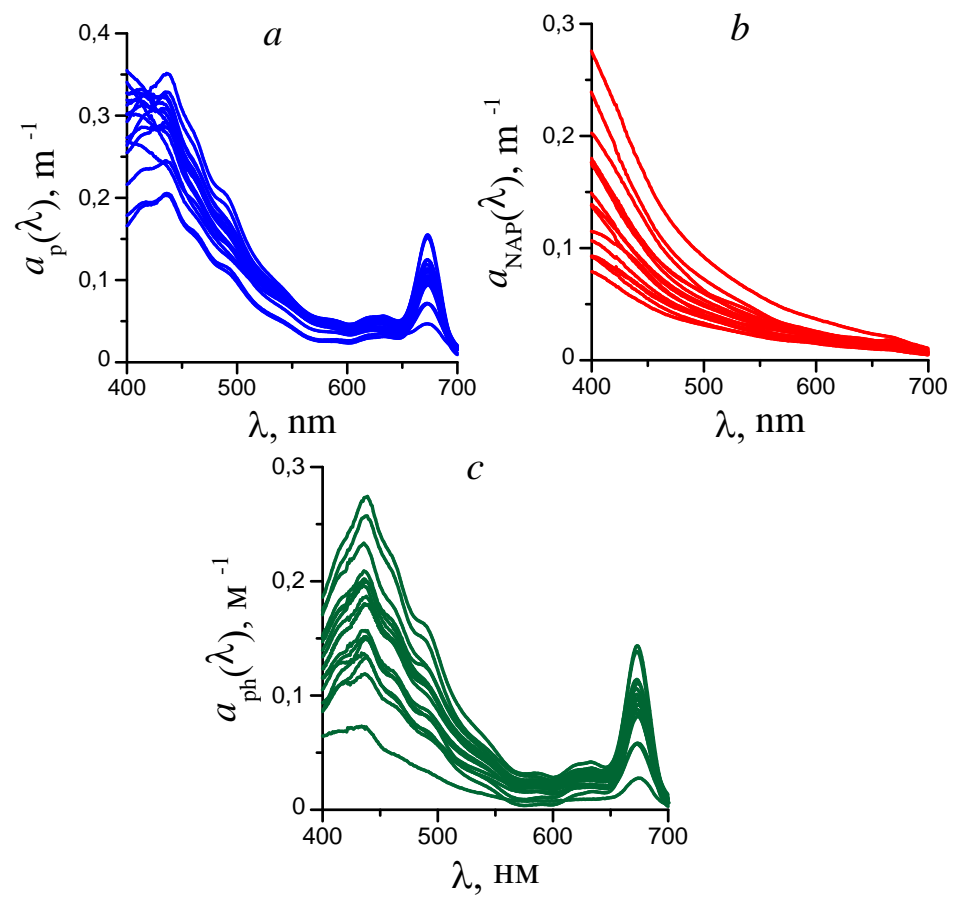

F i g. 5. Spectra of the light absorption coefficients by particles $\left(a_{\mathrm{p}}(\lambda)\right)(a)$, non-algal particles $\left(a_{\mathrm{NAP}}(\lambda)\right)(b)$ and phytoplankton pigments $\left(a_{\mathrm{ph}}(\lambda)\right)(c)$ on the surface and in the water column of the Sea of Azov in the second half of April - the first half of May, 2019

PHYSICAL OCEANOGRAPHY VOL. 27 ISS. 5 (2020) 
The low water transparency was noted in the Azov Sea in spring. The depth $Z_{s}$ was $\sim 2.5 \mathrm{~m}$. Accordingly, the depth of the euphotic layer was $\sim 9 \mathrm{~m}$ at the depth of the sampling stations from 10 to $12 \mathrm{~m}$. That is, euphotic layer was almost the entire water column down to the bottom. An almost uniform vertical distribution of chlorophyll $a$ concentration was observed. The Chl- $a$ value in the sea surface layer varied between stations from 4.9 to $8.8 \mathrm{mg} / \mathrm{m}^{3}$.

The $a_{\mathrm{ph}}(\lambda)$ in Azov Sea was an order of magnitude larger than in the Black Sea (Fig. 3, 5). The R values in the Azov Sea surface layer and water column was less than in the Black Sea waters, and was $2.00 \pm 0.26$ on average (Fig. 3, 5).

The Azov Sea waters differed from the waters of the Black Sea by an order of magnitude larger values of $a_{\mathrm{NAP}}$ (438) $\left(0.11 \pm 0.04 \mathrm{~m}^{-1}\right)$. The relative contribution of $a_{\mathrm{NAP}}(438)$ to $a_{\mathrm{p}}$ (438) was $40 \pm 14 \%$, on average, as in the surface layer of the deep-water part of the Black Sea. $\mathrm{S}_{\mathrm{NAP}}$ ratio was the same as in the Black Sea.

The $a_{\text {СDOм }}(438)$ coefficient in the Azov Sea was almost three times higher than in the Black Sea and was $0.310 \pm 0.058 \mathrm{~m}^{-1}$ on average (Fig. 4). The corresponding $a_{\mathrm{CDOM}}(438)$ contribution to the total light absorption by all suspended and dissolved matter was slightly less than in the Black Sea and equaled $52 \pm 6 \%$. At the same

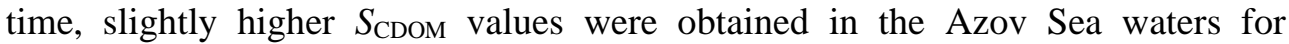
the domain of $350-500 \mathrm{~nm}\left(0.019 \pm 0.001 \mathrm{~nm}^{-1}\right)$ than in the Black Sea waters. In both the Black and Azov seas, the $\mathrm{S}_{\mathrm{CDOM}}$ values are in the range corresponding to the reference data [19]. The $S_{r}$ coefficient in the more eutrophic Azov Sea waters, on the contrary, was lower and amounted to $1.4 \pm 0.1$.

\section{Conclusion}

New data on spatial distribution of the chlorophyll $a$ concentration and the spectral light absorption coefficients by the optically active components in the Black and Azov seas were obtained for the spring period when the seawater hydrophysical characteristics changed. The revealed regularities will improve the accuracy of the existing regional models for the Black Sea and develop appropriate models for the Azov Sea.

\section{REFERENCES}

1. Suslin, V.V., Churilova, T.Ya. and Sosik, H.M., 2008. The SeaWiFS Algorithm of Chlorophyll a in the Black Sea. Marine Ekological Journal = Morskoj Ehkologicheskij Zhurnal, 7(2), pp. 24-42 (in Russian).

2. $\quad$ Finenko, Z.Z., Churilova, T.Ya. and Lee, R.I., 2005. Dynamics of the Vertical Distributions of Chlorophyll and Phytoplankton Biomass in the Black Sea. Oceanology, 45(Suppl. 1), pp. S112-S126.

3. Churilova, T.Y., Suslin, V.V. and Sosik, H.M., 2009. A Spectral Model of Underwater Irradiance in the Black Sea. Physical Oceanography, 19(6), pp. 366-378. doi:10.1007/s11110010-9060-8

4. Vedernikov, V.I., 1989. [Primary Production and Chlorophyll in the Black Sea in Summer and Fall]. In: M. E. Vinogradov and M. V. Flint, eds., 1989. [Structure and Production Characteristics of the Black Sea Plankton Communities]. Moscow: Nauka, pp. 65-83 (in Russian).

5. Sosik, H.M., 1999. Storage of Marine Particulate Samples for Light-Absorption Measurements. Limnology and Oceanography, 44(4), pp. 1139-1141. https://doi.org/10.4319/lo.1999.44.4.1139 
6. Jeffrey, S.W. and Humphrey, G.F., 1975. New Spectrophotometric Equations for Determining Chlorophylls a, b, $\mathrm{c}_{1}$ and $\mathrm{c}_{2}$ in Higher Plants, Algae and Phytoplankton. Biochemie und Physiologie der Pflanzen, 167(2), pp. 191-197. doi:10.1016/S0015-3796(17)30778-3 (in German).

7. IOCCG, 2018. IOCCG Ocean Optics and Biogeochemistry Protocols for Satellite Ocean Colour Sensor Validation; Volume 1.0. Inherent Optical Property Measurements and Protocols: Absorption Coefficient. Dartmouth, NS, Canada: International Ocean-Colour Coordinating Group (IOCCG), 78 p. http://dx.doi.org/10.25607/OBP-119

8. Yentsch, C.S., 1962. Measurement of Visible Light Absorption by Particulate Matter in the Ocean. Limnology and Oceanography, 7(2), pp. 207-217. doi:10.4319/lo.1962.7.2.0207

9. Mitchell, B.G. and Kiefer, D.A., 1988. Chlorophyll a Specific Absorption and Fluorescence Excitation Spectra for Light-Limited Phytoplankton. Deep Sea Research Part A. Oceanographic Research Papers, 35(5), pp. 639-663. doi:10.1016/0198-0149(88)90024-6

10. Tassan, S. and Ferrari, G.M., 1995. An Alternative Approach to Absorption Measurements of Aquatic Particles Retained on Filters. Limnology and Oceanography, 40(8), pp. 1358-1368. https://doi.org/10.4319/lo.1995.40.8.1358

11. Mitchell, B.G., 1990. Algorithms for Determining the Absorption Coefficient for Aquatic Particulates Using the Quantitative Filter Technique. In: SPIE, 1990. Proceedings of SPIE 1302, Ocean Optics X, pp. 137-148. doi:10.1117/12.21440

12. Hoepffner, N. and Sathyendranath, S., 1992. Bio-optical Characteristics of Coastal Waters: Absorption Spectra of Phytoplankton and Pigment Distribution in the Western North Atlantic. Limnology and Oceanography, 37(8), pp. 1660-1679. doi:10.4319/lo.1992.37.8.1660

13. McManus, G.B. and Dawson, R., 1994. Phytoplankton Pigments in the Deep Chlorophyll Maximum of the Caribbean Sea and the Western Tropical Atlantic Ocean. Marine Ecology Progress Series, 113, pp. 199-206. doi:10.3354/meps113199

14. Morel, A., Lazzara, L. and Gostan, J., 1987. Growth Rate and Quantum Yield Time Response for a Diatom to Changing Irradiances (Energy and Color). Limnology and Oceanography, 32(5), pp. 1066-1084. doi:10.4319/lo.1987.32.5.1066

15. Morel, A. and Bricaud, A., 1981. Theoretical results concerning light absorption in a discrete medium and application to specific absorption of phytoplankton. Deep Sea Research Part A. Oceanographic Research Papers, 28(11), pp. 1375-1393. doi:10.1016/0198-0149(81)90039$\mathrm{X}$

16. Efimova, T., Churilova, T., Moiseeva, N. and Zemlianskaia, E., 2019. Spectral Features of Particulate Light Absorption in the Black Sea in Winter. In: SPIE, 2019. Proceedings of SPIE 11208, 25th International Symposium on Atmospheric and Ocean Optics: Atmospheric Physics, 112084V. doi:10.1117/12.2540799

17. Churilova, T., Suslin, V., Berseneva, G. and Pryahina, S., 2007. Parameterization of Light Absorption by Phytoplankton, Nonalgal Particles and Coloured Dissolved Organic Matter in the Black Sea. In: Current Problems in Optics of Natural Waters (ONW'2007): Proceedings of 4th International Conference. Nizhny Novgorod, pp. 70-74.

18. Wozniak, B. and Dera, J., 2007. Light Absorption in Sea Water. New York: Springer, 460 p. doi:10.1007/978-0-387-49560-6

19. Green, S.A. and Blough, N.V., 1994. Optical Absorption and Fluortescence Properties of Chromophoric Dissolved Organic Matter in Natural Waters. Limnology and Oceanography, 39(8), pp. 1903-1916. doi:10.4319/lo.1994.39.8.1903

20. Hansell, D.A. and Carlson, C.A., 2014. Biogeochemistry of Marine Dissolved Organic Matter. Amsterdam: Academic Press, 712 p. 
21. Helms, J.R., Stubbins, A., Ritchie, J.D., Minor, E.C., Kieber, D.J. and Mopper, K., 2008. Absorption Spectral Slopes and Slope Ratios as Indicators of Molecular Weight, Source, and Photobleaching of Chromophoric Dissolved Organic Matter. Limnology and Oceanography, 53(3), pp. 955-969. doi:10.2307/40058211

About the authors:

Tatiana V. Efimova, Junior Researcher, Geomatics Research Center, A.O. Kovalevsky Institute of Biology of the Southern Seas of Russian Academy of Sciences (2 Nakhimov Sq., Sevastopol, Russian Federation, 299011), SPIN: 1668-0742, ORCID ID: 0000-0003-3908-4160, tefimova@ibssras.ru

Tatiana Ya. Churilova, Leading Researcher, Head of Geomatics Research Center, A.O. Kovalevsky Institute of Biology of the Southern Seas of Russian Academy of Sciences (2 Nakhimov Sq., Sevastopol, Russian Federation, 299011), Ph. D. (Biol.), SPIN: 2238-9533, ORCID ID: 0000-0002-0045-7284, tanya.churilova@ibss-ras.ru

Elena Yu. Skorokhod, Junior Researcher, Geomatics Research Center, A.O. Kovalevsky Institute of Biology of the Southern Seas of Russian Academy of Sciences (2 Nakhimov Sq., Sevastopol, Russian Federation, 299011), SPIN: 3314-5775, ORCID ID: 0000-0002-3057-3964, elenaskorokhod@ibss-ras.ru

Nataliya A. Moiseeva, Junior Researcher, Geomatics Research Center, A.O. Kovalevsky Institute of Biology of the Southern Seas of Russian Academy of Sciences (2 Nakhimov Sq., Sevastopol, Russian Federation, 299011), ORCID ID: 0000-0003-1356-7981, Scopus Author ID: 57194431032, Author ID 959717 SPIN 8946-3315, nataliya-moiseeva@yandex.ru

Ekaterina A. Zemlianskaia, Leading Engineer, Geomatics Research Center, A.O. Kovalevsky Institute of Biology of the Southern Seas of Russian Academy of Sciences (2 Nakhimov Sq., Sevastopol, Russian Federation, 299011), SPIN: 5277-9962, ORCID ID: 0000-0003-1360-6581, ekaterinakoval@hotmail.com

Contribution of the authors:

Tatiana V. Efimova - writing the article, sampling, data processing and analysis of the results

Tatiana Ya. Churilova - the problem statement, writing the article

Elena Yu. Skorokhod - data processing

Nataliya A. Moiseeva - data processing

Ekaterina A. Zemlianskaia - sampling, drawing

All the authors have read and approved the final manuscript.

The authors declare that they have no conflict of interest. 